\title{
Multicomponent Biosorption of Heavy Metals from Aqueous Solutions: A Review
}

\author{
Mohammed Abdulaziz ${ }^{*}$, Sardorbek Musayev² \\ ${ }^{1}$ Department of Environmental Health, Faculty of Public Health and Health Informatics, \\ Umm Al-Qura University, Makkah, Saudi Arabia \\ ${ }^{2}$ Department of Civil and Environmental Engineering, University of Connecticut, \\ Storrs, Connecticut, USA
}

Received: 4 September 2016

Accepted: 20 December 2016

\begin{abstract}
Biosorption is the most widely effective, low-cost, and eco-friendly technology for the removal of heavy metals from industrial wastewaters. Several biomaterials have been investigated for their potential to sequester heavy metals from aqueous solutions and show good biosorption capacity. Although the industrial effluents contain a mixture of metal ions, most biosorption studies have been carried out to examine the removal of metal ions in a single rather than a multicomponent system. This review highlights the biosorption of heavy metals in binary and ternary systems by various biomaterials reported in literature, focusing on the factors affecting metal uptake. The review covers the applicable adsorption isotherm models used to analyze and predict the equilibrium data in a multicomponent system.
\end{abstract}

Keywords: biosorption, heavy metals, multicomponent system, adsorption isotherm

\section{Introduction}

A wide spectrums of hazardous substances contaminate the environment due to industrial discharge in the form of wastewater that contains industrial processed toxic heavy metals from electroplating, mining, metal finishing, leather tanning, metallurgy, electronics, fertilizers, chemical manufacturing, and petroleum industries [1-2].

Environmental contamination and public health concerns draw significant implications because of their potential toxicity, non-biodegradability, and tendency to accumulate in the tissues of living organisms [3]. Heavy metals pose various acute and chronic disorders such as kidney damage, liver damage, gastrointestinal distress,

*e-mail: dr.mohammed012@yahoo.com nervous deterioration, pulmonary fibrosis, renal edema, skin diseases, and cancer [4-6].

Several state and international agencies in industrialized countries have enforced strict regulations and legislation to control heavy metal pollution. These regulations designate permissible limits on industrially discharged metals into public sewage systems, and on land and in aquatic environments. Hence, industries need to remove heavy metals from their wastewater before discharging to the environment [7].

Traditional technologies such as chemical precipitation, reverse osmosis, ion exchange, electro-dialysis, and membrane filtration have been implemented to sequester heavy metals from industrial wastewater. However, they pose some limitations with their high cost, low efficiency, high energy consumption, and the generation of toxic sludge that requires further careful disposal [8]. 
Alternative technology to overcome these limitations is in the interest of research and development. Adsorption technology confirms the effective removal of trace concentrations of heavy metals from wastewater. Moreover, it is an environmentally feasible, highly efficient, and cost-effective technology compared to other methods [9].

Metal ions in liquid phase adhere to the surface of solid materials in the adsorption process. Activated carbon is the most widely used adsorbent for the removal of heavy metals from industrial wastewaters. Commercially available activated carbon remains expensive and requires physical and chemical modification to improve its efficiency [10]. This advances to delve into new inexpensive adsorbent materials to existing activated carbon. [11].

The biosorption technology that utilizes naturally available biomaterials for the treatment of wastewater has been proven as a promising emerging technology that can be demonstrated as an alternative to traditional technologies, including activated carbon adsorption [12-13].

Only a few studies have been conducted for examining different metals competition for the adsorption sites on biosorbents, even though industrial wastewater contains more heavy metals. This paper reviews the biosorption of heavy metals in a multicomponent system by focusing on the applied adsorption models.

\section{Biosorption of Heavy Metals}

Biosorption can be defined as a physico-chemical process that utilizes biomaterials for the removal of substances from aqueous solutions. In this process, the dissolved molecules (adsorbate) in the solvent are attached to the surface of biomaterials (biosorbent) [14].

The complex composition of biomaterials implies the presence of the variety of functional groups that have the ability to bind the heavy metals as they are brought into contact in aqueous solutions [15]. The mechanism by which the metal species attached to the surface biomaterials may involve physical adsorption, complexation (chelation and covalent bonding), ion exchange, oxidation/reduction, and micro-precipitation [16].

The physical adsorption is mainly due to electrostatic attraction and van der waals forces. Ion exchange means that one ion on the surface of biomaterials is replaced by a metal ion in the solution. The complexation may be due to electrostatic attraction between the ions of opposite charges, resulting in reducing the distance and forming what termed ion pairs or the formation of covalent bonds. Micro-precipitation involves the deposition of electrically neutral metal on the surface of biomaterials without the formation of bonds. Metal species can be transformed to another due to oxidation-reduction reactions, which may facilitate the formation of species with a higher affinity for the adsorption sites under specific conditions. The biosorption mechanisms reflect the definition of the biosorption process as a physico-chemical process independent of metabolism.
An early attempt at the removal of copper by fungal spores of T. tritici and U. crameri was done by L. Hecke in 1902. During the 1970s, research efforts were directed toward the use of biomaterials for the removal of heavy metals from aqueous solutions. These efforts expanded and the first patent on the use of biosorption technology in the removal of uranium and thorium from aqueous solutions was granted to B. Volesky and M. Tsezos in 1982 [17].

In the last two decades several biomaterials were investigated for their ability to sequester heavy metals from wastewaters. A wide range of biomaterials has been investigated for the potential to remove heavy metals from synthetic and real wastewaters. These biosorbents are derived from different sources such as bacteria, fungi, algae, agricultural waste, and forest plants (Table 1).

Table 1. Biomaterials used for the removal of heavy metals.

\begin{tabular}{|c|c|c|c|}
\hline Biomaterial & Metal & $\begin{array}{c}\text { Maximum } \\
\text { adsorption } \\
\text { capacity } \\
(\mathrm{mg} / \mathrm{g})\end{array}$ & References \\
\hline \multicolumn{4}{|c|}{ Bacteria } \\
\hline \multirow{2}{*}{ Bacillus laterosporus } & $\mathrm{Cr}(\mathrm{VI})$ & 72.6 & \multirow{2}{*}[18]{} \\
\hline & $\mathrm{Cd}(\mathrm{II})$ & 159.5 & \\
\hline $\begin{array}{c}\text { Plesiomonas } \\
\text { shigelloides }\end{array}$ & $\mathrm{Cd}(\mathrm{II})$ & 106.7 & [19] \\
\hline \multirow{2}{*}{$\begin{array}{c}\text { Staphylococcus } \\
\text { xylosus }\end{array}$} & $\mathrm{Cd}(\mathrm{II})$ & 250 & \multirow{2}{*}[20]{} \\
\hline & $\mathrm{Cr}(\mathrm{VI})$ & 143 & \\
\hline \multirow{2}{*}{ Pseudomonas putida } & $\mathrm{Pb}(\mathrm{II})$ & 270.4 & \multirow{2}{*}[21]{} \\
\hline & $\mathrm{Cu}(\mathrm{II})$ & 96.9 & \\
\hline $\begin{array}{l}\text { Thiobacillus } \\
\text { ferrooxidans }\end{array}$ & $\mathrm{Zn}(\mathrm{II})$ & 172.4 & {$[22]$} \\
\hline Bacillus pumilus & $\mathrm{Pb}(\mathrm{II})$ & 93.24 & {$[23]$} \\
\hline Exiguobacterium $\mathrm{sp}$ & $\mathrm{Cd}(\mathrm{II})$ & 15.6 & {$[24]$} \\
\hline \multicolumn{4}{|c|}{ Fungi } \\
\hline $\begin{array}{c}\text { Saccharomyces } \\
\text { cerevisiae }\end{array}$ & $\mathrm{Pb}(\mathrm{II})$ & 72.5 & {$[25]$} \\
\hline Microsphaeropsis sp & $\mathrm{Cd}(\mathrm{II})$ & 247.5 & {$[26]$} \\
\hline \multirow{2}{*}{ Trametes versicolor } & $\mathrm{Pb}(\mathrm{II})$ & 208.3 & \multirow{2}{*}[27]{} \\
\hline & $\mathrm{Cd}(\mathrm{II})$ & 166.6 & \\
\hline \multirow{2}{*}{ Aspergillus niger } & $\mathrm{Cu}(\mathrm{II})$ & 48.54 & \multirow{2}{*}[28]{} \\
\hline & $\mathrm{Pb}(\mathrm{II})$ & 56.50 & \\
\hline Aspergillus sydoni & $\mathrm{Cr}(\mathrm{VI})$ & 9.07 & [29] \\
\hline $\begin{array}{l}\text { Cephalosporium } \\
\text { aphidicola }\end{array}$ & $\mathrm{Pb}(\mathrm{II})$ & 36.91 & {$[30]$} \\
\hline Penicillium italicum & $\mathrm{Zn}(\mathrm{II})$ & 0.2 & {$[31]$} \\
\hline \multicolumn{4}{|c|}{ Algae } \\
\hline \multirow{2}{*}{ Cystoseira indicia } & $\mathrm{Cu}(\mathrm{II})$ & 103.09 & \multirow{2}{*}{ [4] } \\
\hline & $\mathrm{Co}(\mathrm{II})$ & 59.5 & \\
\hline
\end{tabular}


Table 1. Continued.

\begin{tabular}{|c|c|c|c|}
\hline Padina australis & $\mathrm{Ni}(\mathrm{II})$ & 22 & {$[32]$} \\
\hline \multirow{5}{*}{ Sargassum sp } & $\mathrm{Pb}(\mathrm{II})$ & 240.35 & \multirow{5}{*}[33]{} \\
\hline & $\mathrm{Cu}(\mathrm{II})$ & 62.9 & \\
\hline & $\mathrm{Cd}(\mathrm{II})$ & 85.4 & \\
\hline & $\mathrm{Zn}(\mathrm{II})$ & 32.7 & \\
\hline & $\mathrm{Ni}(\mathrm{II})$ & 35.8 & \\
\hline Bifurcaria bifurcate & $\mathrm{Cd}(\mathrm{II})$ & 73.1 & {$[34]$} \\
\hline \multirow{2}{*}{ Macrocystis pyrifera } & $\mathrm{Zn}$ (II) & 59.5 & \multirow{2}{*}[35]{} \\
\hline & $\mathrm{Cd}(\mathrm{II})$ & 100 & \\
\hline Chlorella miniata & $\mathrm{Cr}(\mathrm{III})$ & 41.12 & {$[36]$} \\
\hline \multirow{3}{*}{ Fucus spiralis } & $\mathrm{Cd}(\mathrm{II})$, & 42.1 & \multirow{3}{*}[37]{} \\
\hline & $\mathrm{Zn}(\mathrm{II})$ & 34.3 & \\
\hline & $\mathrm{Pb}(\mathrm{II})$ & 43.5 & \\
\hline Oedogonium $\mathrm{sp}$ & $\mathrm{Cd}(\mathrm{II})$ & 80.4 & {$[38]$} \\
\hline Biomaterial & Metal & $\begin{array}{c}\text { Maximum } \\
\text { adsorption } \\
\text { capacity } \\
(\mathrm{mg} / \mathrm{g})\end{array}$ & References \\
\hline \multicolumn{4}{|c|}{ Algae } \\
\hline \multirow{2}{*}{ Spirogyra sp } & $\mathrm{Cr}(\mathrm{VI})$ & 14.7 & [39] \\
\hline & $\mathrm{Pb}(\mathrm{II})$ & 140 & {$[40]$} \\
\hline \multirow{2}{*}{ Oedogonium hatei } & $\mathrm{Cr}(\mathrm{VI})$ & 31 & [41] \\
\hline & $\mathrm{Ni}(\mathrm{II})$ & 40.9 & {$[42]$} \\
\hline \multicolumn{4}{|c|}{ Plants } \\
\hline \multirow{2}{*}{ Typha domingensis } & $\mathrm{Ni}(\mathrm{II})$ & 4.51 & \multirow{2}{*}{ [43] } \\
\hline & $\mathrm{Cd}(\mathrm{II})$ & 28.49 & \\
\hline $\begin{array}{l}\text { Lagerstroemia } \\
\text { speciosa }\end{array}$ & $\mathrm{Cr}(\mathrm{VI})$ & 20.4 & [44] \\
\hline \multirow{3}{*}{ Corn silk } & $\mathrm{Cu}(\mathrm{II})$, & 96.15 & \multirow{3}{*}[45]{} \\
\hline & $\mathrm{Co}(\mathrm{II})$ & 90.09 & \\
\hline & $\mathrm{Ni}$ (II) & 76.92 & \\
\hline \multirow{2}{*}{ Asplenium nidus $\mathrm{L}$} & $\mathrm{Ni}(\mathrm{II})$ & 9.2 & \multirow{2}{*}{ [46] } \\
\hline & $\mathrm{Pb}(\mathrm{II})$ & 12.24 & \\
\hline Cyclosorus interruptus & $\mathrm{Pb}(\mathrm{II})$ & 46.25 & {$[47]$} \\
\hline \multirow{2}{*}{ Diplotaxis harra } & $\mathrm{Cd}(\mathrm{II})$ & 25.24 & \multirow{2}{*}{ [48] } \\
\hline & $\mathrm{Co}(\mathrm{II})$ & 33.02 & \\
\hline Acidosasa edulis & $\mathrm{Cu}(\mathrm{II})$ & 2.51 & [49] \\
\hline
\end{tabular}

\section{Biosorption in a Multicomponent System}

Since industrial effluent often contains different metal ions, great attention should be paid for the competition between these ions for the binding sites on the surface of the biosorbent. Experimental studies testing the effects of multicomponents on the biosorption process represent a better simulation for the real wastewater treatment than the single studies. Taking into consideration the limited active site on the surface of the biosorbent, it is granted that the biosorption capacity for a specific metal ion in a multicomponent system is less than that of a single system [50].

The results of many research works showed strong competition between metal ions for the adsorption sites. The amount of $\mathrm{Cr}(\mathrm{VI})$ adsorbed per unit weight of $R$. arrhizus was decreased with increasing concentrations of Fe (III) ions showing an antagonistic combined effect [51].

Experimental work done by Fagundes-Klen et al. [52] showed that in the presence of high concentrations of cadmium, the amount of zinc adsorbed by S. filipendula decreased to $56.8 \%$ in comparison with the monocomponent system. S. filipendula showed a preference for zinc ions more than cadmium ions, attributing that to smaller ionic radius, the smaller number of coordination, and the higher ionization potential of zinc.

It is worth noting that the ionic concentration of metal ions has a significant effect on the adsorption capacity of metal ions in a multi-component system. The higher ionic concentration provides a driving force that overcomes the mass resistance transfer of metal ions during the biosorption process. Although the lead ions have a higher affinity than the copper ions for the biosorption on algae Gelidium, it has been observed that the copper uptake was higher than lead due to the higher initial concentration of copper [53]. Similar higher affinity for lead ions compared to the copper ions was observed for biosorption on pine cone shells. The metals (lead and copper) uptake by pine cone shells in a binary system was inhibited slightly in comparison to their uptake in a single system [54].

Electronegativity and atomic weight of heavy metals can play an important role in the biosorption of heavy metals in a multicomponent system. Study on the biosorption of $\mathrm{Ni}$ (II) and $\mathrm{Zn}$ (II) on wheat straw in a binary system revealed competition between two metals for the adsorption sites, with a higher preference for $\mathrm{Zn}$ (II) than Ni (II) [55]. The lower electronegativity and higher atomic weight of $\mathrm{Zn}$ (II) than $\mathrm{Ni}$ (II) provide better physical characteristics for $\mathrm{Zn}$ (II) to be adsorbed than $\mathrm{Ni}$ (II). The oxygen-containing group on the wheat straw (negative sites) repels the $\mathrm{Ni}$ (II) more than $\mathrm{Zn}$ (II).

Temperature was found to be the most important factor affecting the biosorption of $\mathrm{Cr}$ (III), $\mathrm{Cu}$ (II), and $\mathrm{Zn}$ (II) by wine-processing waste sludge (WPWS) in a ternary system [56]. The removal of these metals in a mixture by WPWS follows the trend $\mathrm{Cr}$ (III) $>\mathrm{Cu}$ (II) $>\mathrm{Zn}$ (II). Despite that, $\mathrm{Cr}$ (III) sorption was lower than that of $\mathrm{Cu}$ (II) at $10^{\circ} \mathrm{C}$, whereas at $30^{\circ} \mathrm{C}$ the sorption of $\mathrm{Cr}$ (III) was higher than the sorption of $\mathrm{Cu}$ (II).

Biosorption of heavy metals from a multicomponent system has been investigated by many researchers and some results are presented in Table 2. Conducting a basic search in the web of science (WoS), we found 10,710 results regarding the topic of biosorption. These results refined with "multicomponent" as a topic narrowed the results to 101 articles. Further refinement using "heavy metals" resulted in 60 articles. After sorting these articles 
Table 2. Biosorption of heavy metals in a multicomponent system and the models applied.

\begin{tabular}{|c|c|c|c|}
\hline Multicomponent system & Biosorbent & Biosorption preference & References \\
\hline $\mathrm{Ni}-\mathrm{Zn}$ & Wheat straw & $\mathrm{Zn}(\mathrm{II})>\mathrm{Ni}(\mathrm{II})$ & {$[55]$} \\
\hline $\mathrm{Cr}-\mathrm{Fe}$ & Rhizopus arrhizus & $\mathrm{Cr}(\mathrm{VI})>\mathrm{Fe}(\mathrm{III})$ & {$[51]$} \\
\hline $\mathrm{Cd}-\mathrm{Zn}$ & Sargassum filipendula & $\mathrm{Zn}(\mathrm{II})>\mathrm{Cd}(\mathrm{II})$ & {$[52]$} \\
\hline $\mathrm{Pb}-\mathrm{Cu}, \mathrm{Pb}-\mathrm{Cd}$ and $\mathrm{Pb}-\mathrm{Zn}$ & algae Gelidium & $\mathrm{Pb}(\mathrm{II})>\mathrm{Cu}(\mathrm{II}), \mathrm{Pb}(\mathrm{II})>\mathrm{Cd}(\mathrm{II}), \mathrm{Pb}(\mathrm{II})>\mathrm{Zn}(\mathrm{II})$ & {$[53]$} \\
\hline $\mathrm{Cr}(\mathrm{VI})-\mathrm{Fe}(\mathrm{III})-\mathrm{Cu}(\mathrm{II})$ & Rhizopus arrhizus & $\begin{array}{c}\mathrm{Cr}(\mathrm{VI})> \\
\mathrm{Fe}(\mathrm{III})>\mathrm{Cu}(\mathrm{II})\end{array}$ & {$[57]$} \\
\hline $\mathrm{Pb}-\mathrm{Cu}$ & Pine cone shell & $\mathrm{Pb}(\mathrm{II})>\mathrm{Cu}(\mathrm{II})$ & {$[54]$} \\
\hline $\mathrm{Cr}-\mathrm{Cu}-\mathrm{Zn}$ & Wine-processing waste sludge & $\mathrm{Cr}>\mathrm{Cu}(\mathrm{II})>\mathrm{Zn}(\mathrm{II})$ & {$[56]$} \\
\hline $\mathrm{Ni}-\mathrm{ZN}-\mathrm{Pb}$ & Arthrospira platensis & $\mathrm{Pb}(\mathrm{II})>\mathrm{Zn}(\mathrm{II})>\mathrm{Ni}(\mathrm{II})$ & {$[58]$} \\
\hline $\mathrm{Cu}-\mathrm{Co}-\mathrm{Cr}-\mathrm{Fe}-\mathrm{Hg}-\mathrm{Ni}-\mathrm{Zn}-\mathrm{U}$ & Oedogonium $s p$ & $\mathrm{Hg}>\mathrm{U}>\mathrm{Zn}>\mathrm{Fe}>\mathrm{Cu}>\mathrm{Cr}>\mathrm{Ni}>\mathrm{Co}$ & [59] \\
\hline $\mathrm{Zn}-\mathrm{Ni}-\mathrm{Cu}$ & Sargassum ilicifolium & $\mathrm{Zn}(\mathrm{II})>\mathrm{Ni}(\mathrm{II})>\mathrm{Cu}(\mathrm{II})$ & {$[60]$} \\
\hline $\mathrm{Cu}-\mathrm{Ni}$ & Sargassum filipendula & $\mathrm{Cu}(\mathrm{II})>\mathrm{Ni}(\mathrm{II})$ & {$[61]$} \\
\hline $\mathrm{Pb}-\mathrm{Cd}$ & Saccharomyces cerevisiae cell & $\mathrm{Pb}(\mathrm{II})>\mathrm{Cd}(\mathrm{II})$ & {$[62]$} \\
\hline $\mathrm{Cd}-\mathrm{Pb}-\mathrm{Cu}-\mathrm{Ni}$ & Grapefruit biomass & $\mathrm{Pb}(\mathrm{II})>\mathrm{Cu}(\mathrm{II})>\mathrm{Ni}(\mathrm{II})>\mathrm{Cd}(\mathrm{II})$ & {$[63]$} \\
\hline $\mathrm{Cd}-\mathrm{Zn}$ & Activated sludge & $\mathrm{Cd}(\mathrm{II})>\mathrm{Zn}(\mathrm{II})$ & {$[64]$} \\
\hline $\mathrm{Pb}-\mathrm{Cu}$ & Almond shell & $\mathrm{Pb}(\mathrm{II})>\mathrm{Cu}(\mathrm{II})$ & {$[65]$} \\
\hline $\mathrm{Zn}-\mathrm{Co}-\mathrm{Cd}$ & Aspergillus niger & $\mathrm{Cd}(\mathrm{II})>\mathrm{Co}(\mathrm{II})>\mathrm{Zn}(\mathrm{II})$ & {$[66]$} \\
\hline $\mathrm{Cu}-\mathrm{Co}$ & Cystoseira indicia & $\mathrm{Cu}(\mathrm{II})>\mathrm{Co}(\mathrm{II})$ & {$[4]$} \\
\hline
\end{tabular}

from the highest to the lowest number of citations, we listed the top-10 highly cited research articles in Table 3.

\section{Modeling Multicomponent Adsorption}

For designing a biosorption process, suitable models should be used to analyze the experimentally obtained equilibrium data, understand the process mechanism, and predict process performance. An adsorption isotherm describes the equilibrium between the concentration of adsorbate in solution and its quantity per unit mass of adsorbent. This can be mathematically expressed using the mass balance formula:

$$
q_{e}=\frac{\left(C_{i}-C_{e}\right) \times V}{m}
$$

...where $\mathrm{q}_{\mathrm{e}}$ is the metal ion adsorbed (mg metal ion/ $\mathrm{g}$ biosorbent) at equilibrium, $\mathrm{V}$ is the volume of the solution (L), $\mathrm{C}_{\mathrm{i}}$ and $\mathrm{C}_{\mathrm{e}}$ are the initial and equilibrium concentration of metal ion $(\mathrm{mg} / \mathrm{L})$, and $\mathrm{m}$ is the dry weight of the biosorbent $(\mathrm{g})$.

The adsorption isotherm can be used to compare between the biosorbents for their capacity to uptake heavy metals from wastewater and the affinity of different metal ions to the same biomaterial. Several adsorption isotherm models have been used to describe the equilibrium isotherm of the biosorption process.
Taking into account the competition of different metals for the adsorption sites on the surface of a biosorbent, adsorption modeling is needed for better understanding and designing of the system. Since obtaining the equilibrium data from a multicomponent system is difficult, the multicomponent adsorption isotherm models have been developed using the equilibrium data form the single system with additional information from a multicomponent system [67].

Unfortunately, few adsorption isotherm models have been developed to describe the equilibrium data in a multicomponent system. Bulter and Ockrent (1930) were the first to extend the Langmuir model for competitive adsorption. Based on the assumptions that the adsorption is monolayer and one site on the surface of the biosorbent is available for one adsorbed molecule, the Langmuir isotherm is given by the following equation:

$$
q_{e}=\frac{K_{L} q_{\max } C_{e}}{1+K_{L} C_{e}}
$$

... where $\mathrm{q}_{\max }$ is the maximum biosorption capacity of the adsorbent $(\mathrm{mg} / \mathrm{g})$ and $\mathrm{K}_{\mathrm{L}}$ is the Langmuir biosorption constant (L/mg). The multicomponent Langmuir adsorption isotherm model can be expressed as follows [54]:

$$
q_{e i}=\frac{K_{L, i} q_{\max } C_{e, i}}{1+\sum_{j=1}^{N} K_{L, j} C_{e, j}}
$$


Table 3. Top-10 highly cited research articles on the biosorption of heavy metals from a multicomponent system.

\begin{tabular}{|c|c|c|c|}
\hline Article & Authors & Journal & Times cited \\
\hline $\begin{array}{l}\text { Equilibrium Isotherm Studies for the Sorption of } \\
\text { Divalent Metal Ions onto Peat: Copper, Nickel } \\
\text { and Lead Single Component Systems }\end{array}$ & $\begin{array}{l}\text { Ho, Y.S., Porter, J.F. and } \\
\text { McKay, G. }\end{array}$ & $\begin{array}{l}\text { Water, Air, and Soil } \\
\text { Pollution (2002), 141, } \\
\text { 1-33. }\end{array}$ & 501 \\
\hline $\begin{array}{l}\text { Modeling of the Proton-Metal Ion Exchange in } \\
\text { Biosorption }\end{array}$ & $\begin{array}{l}\text { Schiewer, S. and Volesky } \\
\text { B. }\end{array}$ & $\begin{array}{c}\text { Environmental Science } \\
\text { Technology (1995), 29, } \\
\text { 3,049-3,058. }\end{array}$ & 212 \\
\hline $\begin{array}{l}\text { Description of two-metal biosorption equilibria } \\
\text { by Langmuir-type models }\end{array}$ & $\begin{array}{l}\text { Chong, K. H. and } \\
\text { Volesky, B. }\end{array}$ & $\begin{array}{c}\text { Biotechnology and } \\
\text { Bioengineering (1996), 47, } \\
\text { 451-460. }\end{array}$ & 198 \\
\hline Biosorption of metals in brown seaweed biomass & $\begin{array}{l}\text { Figueira, M. M., } \\
\text { Volesky, B., Ciminelli V. } \\
\text { S. T. and Felicity } \\
\text { A. R. }\end{array}$ & $\begin{array}{l}\text { Water Research (2000), 34, } \\
\text { 196- } 204 .\end{array}$ & 195 \\
\hline $\begin{array}{c}\text { Equilibrium modelling of single and binary } \\
\text { adsorption of cadmium and nickel onto bagasse } \\
\text { fly ash }\end{array}$ & $\begin{array}{l}\text { Srivastava, V.C., Mall, } \\
\text { I.D., Mishra, I.M. }\end{array}$ & $\begin{array}{l}\text { Chemical Engineering } \\
\text { Journal }(2006), 117,79-91 .\end{array}$ & 180 \\
\hline $\begin{array}{c}\text { Comparative study of biosorption of heavy } \\
\text { metals using different } \\
\text { types of algae }\end{array}$ & $\begin{array}{l}\text { Romera, E., Gonzalez, } \\
\text { F., Ballester, A., } \\
\text { Blazquez, M.L., Munoz, } \\
\text { J.A. }\end{array}$ & $\begin{array}{l}\text { Bioresource Technology } \\
(2007), 98,3,344-3,353 \text {. }\end{array}$ & 162 \\
\hline $\begin{array}{l}\text { Ion binding to natural organic matter: General } \\
\text { considerations and the NICA-Donnan model }\end{array}$ & $\begin{array}{l}\text { Koopal L.K., Saito T., } \\
\text { Pinheiro J.P., Riemsdijk, } \\
\text { W.H. van. }\end{array}$ & $\begin{array}{l}\text { Colloids and Surfaces } \\
\text { A: Physicochem. Eng. } \\
\text { Aspects }(2005), 265,40-54\end{array}$ & 128 \\
\hline $\begin{array}{c}\text { Equilibrium modelling of individual and } \\
\text { simultaneous biosorption of chromium(VI) and } \\
\text { nickel(II) onto dried activated sludge }\end{array}$ & $\begin{array}{l}\text { Aksu, Z., Acıkel, U. A., } \\
\text { Kabasakal, E., Tezer S. }\end{array}$ & $\begin{array}{l}\text { Water Research (2002), 36, } \\
\qquad 3,063-3,073\end{array}$ & 127 \\
\hline $\begin{array}{l}\text { Modeling Multi-Metal Ion Exchange in } \\
\text { Biosorption }\end{array}$ & $\begin{array}{l}\text { Schiewer, S. and Volesky } \\
\text { B. }\end{array}$ & $\begin{array}{c}\text { Environmental Science } \\
\text { Technology (1996), 30, } \\
\text { 2,921-2,926 }\end{array}$ & 101 \\
\hline Multicomponent biosorption in fixed beds & $\begin{array}{l}\text { Kratochvil, D. and } \\
\text { Volesky, B }\end{array}$ & $\begin{array}{c}\text { Water Research (2000), 34, } \\
\text { 3,186-3,196 }\end{array}$ & 67 \\
\hline
\end{tabular}

... where $\mathrm{C}_{e, i}$ and $\mathrm{q}_{\mathrm{e}, \mathrm{i}}$ are the equilibrium concentration and the adsorbed quantity of the " $i$ " component per unit gram of biosorbents, respectively. $\mathrm{C}_{\mathrm{e}, \mathrm{j}}$ is the equilibrium concentration of the " $\mathrm{j}$ " component in the solution. $\mathrm{q}_{\max }$, $\mathrm{K}_{\mathrm{L}, \mathrm{I}}$, and $\mathrm{K}_{\mathrm{L}, \mathrm{j}}$ are the Langmuir adsorption constants derived from the corresponding individual Langmuir model equation.

The multicomponent Langmuir adsorption isotherm is further modified to describe the competition of metal ions and their interaction in the mixtures. The interaction factor is incorporated to Eq. 3 as [44]:

$$
q_{e i}=\frac{K_{L, i} q_{\max }\left(C_{e, i} / n_{i}\right)}{1+\sum_{j=1}^{N} K_{L, j}\left(C_{e, j} / n_{j}\right)}
$$

... where $n_{i}$ and $n_{j}$ are the correction factors for " $i$ " and " $j$ " metals that can be estimated from the multicomponent data. $\mathrm{q}_{\max }, \mathrm{K}_{\mathrm{L}, \mathrm{I}}$, and $\mathrm{K}_{\mathrm{L}, \mathrm{j}}$ are calculated from the individual Langmuir isotherm equation.

Based on the assumption of partial competition between metals for the adsorption sites, the multicomponent Langmuir adsorption isotherm for binary mixture can be expressed as [55]:

$$
\begin{gathered}
q_{1}=\frac{\left(q_{\max 1}-q_{\max 2}\right) K_{L, 1} C_{1}}{1+K_{L, 1} C_{1}}+\frac{q_{\max 1} K_{L, 1} C_{1}}{1+K_{L, 1} C_{1}+K_{L, 2} C_{2}} \\
q_{2}=\frac{q_{\max 2} K_{L, 2} C_{2}}{1+K_{L, 1} C_{1}+K_{L, 2} C_{2}}
\end{gathered}
$$

The right-hand side of Eq. (5) and Eq. (6) represent the amount of metal " 1 " and metal " 2 " adsorbed with competition with each other, respectively, whereas the left side of Eq. (6) accounts for the amount of metal " 2 ", adsorbed without competition with metal "1."

Freundlich proposed an empirical isotherm equation assuming heterogeneity of adsorption sites. The Freundlich equation is:

$$
q_{e}=K_{f} C_{e}^{1 / n}
$$

... where " $\mathrm{K}_{\mathrm{f}}$ " is a measure of the capacity of the adsorbent and " $n$ " is a measure of how affinity for the adsorbate changes with changes in adsorption density. 
The Freundlich multicomponent isotherm model, which is known as the Sheindorf-Rebuhn-Sheintuch (SRS), equation can be written as [55]:

$$
q_{e, i}=K_{f, i} C_{e, i}\left(\sum_{j=1}^{k} a_{i j} C_{e, j}\right)^{n_{i}-1}
$$

For a binary system the model can be expressed as:

$$
\begin{aligned}
& \frac{C_{1}}{C_{2}}=\frac{1}{C_{2}} \beta_{1}-a_{12} \\
& \frac{C_{2}}{C_{1}}=\frac{1}{C_{2}} \beta_{2}-a_{21}
\end{aligned}
$$

... where $\boldsymbol{\beta}_{\mathrm{i}}=\left(\frac{\mathrm{q}_{\mathrm{i}}}{\boldsymbol{K}_{f, i} \mathrm{C}_{\mathrm{i}}}\right)^{\mathbf{1} \boldsymbol{m}_{\boldsymbol{i}}-\mathbf{1}}$ and $\mathrm{a}_{\mathrm{ij}}$ is the competition coefficient with $\mathrm{a}_{\mathrm{ij}}=1 / a_{i j}$. The Freundlich constants $\mathrm{Ki}$ and $\mathrm{m}_{\mathrm{i}}$ can be obtained from the Freundlich model for a single system, where $\mathrm{m}_{\mathrm{i}}=1 / n_{i}$. The values of $\mathrm{q}_{\mathrm{i}}$ and $\mathrm{C}_{\mathrm{i}}$ are the metal uptake and equilibrium concentrations of metal " $i$ " in the multicomponent system, respectively.

Both models of the Langmuir and Freundlich multicomponent adsorption isotherm are based on the assumption of the single component models resulting in restricted application of these models to describe adsorption in a multicomponent system. The ideal adsorbed solution theory (IAST) model provides the more accurate description of multicomponent adsorption equilibria [68].

This theory was applied for the adsorption of mixtures from aqueous solutions by Radke and Prausnitz (1972). They assumed that when mixtures of adsorbate are adsorbed simultaneously at the same temperature and spreading pressure as each species would, the adsorbed phase forms an ideal solution. IAST theory uses the thermodynamic approaches to describe the multicomponent adsorption isotherm using single-component adsorption data. The IAST equation can be expressed as [69]:

$$
\pi=\pi_{i}=\frac{R T}{A} \int_{0}^{C_{e, i}^{*}} \frac{q_{e, i}}{C_{e, i}} d C_{e, i}
$$

... where $\pi$ is the spreading pressure of the system (the decrease of surface tension as a result of adsorption), which is equalized with the spreading pressure $\pi_{i}$ of each component "i." The spreading pressure is calculated by integrating $\frac{q_{e, i}}{c_{e, i}}$ over the range from zero to the concentration of solute in a single system that exerts the same spreading pressure of the mixture $C_{e, i}^{*}$ " $\mathrm{R}$ " is the universal gas constant, " $\mathrm{T}$ " is the temperature in Kelvin, and " $\mathrm{A}$ " is the external surface area per unit mass of adsorbent. The integration can be calculated using the obtained data from different adsorption isotherm models of a single system.

The adsorption equilibrium data can be described using the combination of Langmuir and Freundlich adsorption isotherm models. This combination model was developed by Sips 1948 and is known as the Sips model. The expression of the Sips model in a single system is:

$$
q_{e}=\frac{q_{\max }(b C)^{1 / n}}{1+(b C)^{1 / n}}
$$

... where the values of " $\mathrm{b}$," " $\mathrm{q}_{\max }$," and " $n$ " can be obtained by fitting the experimental data to the model. The Sips model has been extended to describe adsorption in a multicomponent system. The equation for the extended Sips model is [70]:

$$
q_{i}=\frac{q_{\max , i} b_{i} C_{i}\left(\sum_{k=1}^{N} b_{k} C_{k}\right)^{1 / n_{i}-1}}{1+\left(\sum_{k=1}^{N} b_{k} C_{k}\right)^{1 / n_{i}}}
$$

... where the values of " $b$," " $q_{\max }$," and " $n$ " are calculated from Eq. (12) and applied in a multicomponent model.

\section{Conclusion}

Biosorption is an effective, low-cost technology for removing heavy metals from industrial wastewater. Most research studies in this field were diverted to test the removal of metals using various types of biomaterials in a single system. Biomaterials have the ability to bind different metals from wastewater with a higher affinity for certain metal ions than others. Many factors such as initial metal concentration, electronegativity, atomic weight, and ionic radius can play important roles in the competition of different ions for the adsorption sites. For designing the process and designing and predicting sorption performance in a multicomponent system, isotherm models were developed to describe the equilibrium data. These models were an extension or modification of the single Freundlich and Langmuir models. It is most important to investigate the simultaneous biosorption of heavy metals because real wastewater doesn't often contain a single metal component. Studying the factors that affect competitive biosorption can help develop adsorption models that fit the equilibrium data obtained from binary or ternary systems adequately.

\section{Acknowledgements}

The authors would like to thank the Institute of Scientific Research and Revival of Islamic Heritage at Umm Al-Qura University (project No. 43509034) for financial support.

\section{References}

1. LESMANA S.O., FEBRIANA N., SOETAREDJO F.E., SUNARSO J., ISMADJI S. Studies on potential applications of 
biomass for the separation of heavy metals from water and wastewater. Biochem. Eng. J, 44 (1), 19, 2009.

2. MISHRA A., TRIPATHI B.D., RAI A.K. Biosorption of $\mathrm{Cr}(\mathrm{VI})$ and $\mathrm{Ni}(\mathrm{II})$ onto Hydrilla verticillata dried biomass. Ecol. Eng. 73, 713, 2014.

3. WANG J., CHEN C. Biosorbents for heavy metals removal and their future. Biotechnol Adv. 27 (2),195, 2009.

4. AKBARI M., HALLAJISANI A., KESHTKAR A.R., SHAHBEIG H., ALI GHORBANIAN S. Equilibrium and kinetic study and modeling of $\mathrm{Cu}$ (II) and $\mathrm{Co}(\mathrm{II})$ synergistic biosorption from $\mathrm{Cu}(\mathrm{II})-\mathrm{Co}$ (II) single and binary mixtures on brown algae $C$. indica. J. Environ. Chem. Eng. 3 (1), 140, 2015.

5. FEBRIANTO J., KOSASIH A.N, SUNARSO J., JU Y.H, INDRASWATI N., ISMADJI S. Equilibrium and kinetic studies in adsorption of heavy metals using biosorbent: a summary of recent studies. J. Hazard. Mater. 162 (2-3), 616, 2009.

6. ABU HASAN H., SHEIKH ABDULLAH S.R., TAN KOFLI N., YEOH S.J. Interaction of environmental factors on simultaneous biosorption of lead and manganese ions by locally isolated Bacillus cereus. J. Ind. Eng. Chem. 37, 295, 2016.

7. TCHOUNWOU P.B., YEDJOU C.G., PATLOLLA A.K., SUTTON D.J. Heavy metal toxicity and the environment. EXS.101,133, 2012.

8. VIJAYARAGHAVAN K., YUN Y.S. Bacterial biosorbents and biosorption. Biotechnol Adv. 26 (3), 266, 2008.

9. GUPTA V.K., SUHAS, NAYAK A., AGARWAL S., CHAUDHARY M., TYAGI I. Removal of Ni (II) ions from water using scrap tire. J. Hazard. Mater. 190, 215, 2014

10. BABEL S., KURNIAWAN T.A. Low-cost adsorbents for heavy metals uptake from contaminated water: a review. J. Hazard. Mater. B 97, 219, 2003.

11. IBRAHIM W.M., HASSAN A.F., AZAB Y.A. Biosorption of toxic heavy metals from aqueous solution by Ulva lactuca activated carbon. EJBAS. 3, 241, 2016.

12. VIMALA R., CHARUMATHI D., DAS N. Packed bed column studies on Cd (II) removal from industrial wastewater by macrofungus Pleurotus platypus. Desalination, 275, 291, 2011.

13. SAHA B., ORVIG C. Biosorbents for hexavalent chromium elimination from industrial and municipal effluents. Coord. Chem. Rev. 254, 2959, 2010.

14. KRATOCHVIL D. AND VOLESKY B. Advances in the biosorption of heavy metals. TIBTECH. 16, 291, 1998.

15. GADD G. M. Biosorption: critical review of scientific rationale, environmental importance and significance for pollution treatment. J. Chem. Technol. Biotechnol. 84, 13, 2009.

16. ROBALDS A., NAJA G. M., KLAVINS M. Highlighting inconsistencies regarding metal biosorption. J. Hazard. Mater. 304, 553, 2016.

17. PARK D., YUN Y-S, PARK J.M. The past, present, and future trends of biosorption. Biotechnol. Bioprocess Eng.15, $86,2010$.

18. ZOUBOULIS A.I., LOUKIDOU M.X., MATIS K.A. Biosorption of toxic metals from aqueous solutions by bacteria strains isolated from metal-polluted soils. Process Biochem. 39, 909, 2004.

19. XUE C., QI P., LI M., LIU Y. Characterization and Sorptivity of the Plesiomonas shigelloides Strain and Its Potential Use to Remove $\mathrm{Cd}^{2+}$ from Wastewater, Water. 8 (6), 241, 2016.

20. ZIAGOVA M., DIMITRIADIS G., ASLANIDOU D., PAPAIOANNOU X., TZANNETAKI E.L., LIAKOPOULOU-KYRIAKIDES, M. Comparative study of $\mathrm{Cd}(\mathrm{II})$ and $\mathrm{Cr}(\mathrm{VI})$ biosorption on Staphylococcus xylosus and Pseudomonas sp. in single and binary mixtures. Bioresour. Technol. 98, 2859, 2007.

21. USLU G., TANYOL M. Equilibrium and thermodynamic parameters of single and binary mixture biosorption of lead (II) and copper (II) ions Pseudomonas putida: effect of temperature. J. Hazard. Mater. 135 B, 87, 2006.

22. LIU H.L., CHEN B.Y, LAN Y.W., CHENG Y.C. Biosorption of $\mathrm{Zn}$ (II) and $\mathrm{Cu}$ (II) by the indigenous Thiobacillus thiooxidans. Chem. Eng. J. 94, 195, 2004.

23. PEPI M., BORRA M., TAMBURRINO S., SAGGIOMO M., VIOLA A., BIFFALI E., BALESTRA C., SPROVIERI M., CASOTTI R. A Bacillus sp. isolated from sediments of the Sarno River mouth, Gulf of Naples (Italy) produces a biofilm biosorbing $\mathrm{Pb}$ (II). Sci. Total Environ. 562, 588, 2016.

24. PARK J. H., CHON H-T. Characterization of cadmium biosorption by Exiguobacterium sp. isolated from farmland soil near $\mathrm{Cu}-\mathrm{Pb}-\mathrm{Zn}$ mine. Environ. Sci. Pollut. Res. 23, $11814,2016$.

25. AMIRNIA S., RAY M. B., MARGARITIS A. Heavy metals removal from aqueous solutions using Saccharomyces cerevisiae in a novel continuous bioreactor-biosorption system. Chem. Eng. J. 264, 863, 2015.

26. XIAO X., LUO S., ZENG G., WEI W., WAN Y., CHEN L., GUO H., CAO Z., YANG L., CHEN J., XI Q. Biosorption of cadmium by endophytic fungus (EF) Microsphaeropsis sp. LSE10 isolated from cadmium hyperaccumulator Solanum nigrum L. Bioresour. Technol. 101, 1668, 2010.

27. SUBBAIAH M.V., YUVARAJA G., VIJAYA Y., KRISHNAIAH A. Equilibrium, kinetic and thermodynamic studies on biosorption of $\mathrm{Pb}(\mathrm{II})$ and $\mathrm{Cd}(\mathrm{II})$ from aqueous solution by fungus (Trametes versicolor) biomass. J. Taiwan Inst. Chem. Eng. 42, 965, 2011.

28. DURSUN A.Y. A comparative study on determination of the equilibrium, kinetic and thermodynamic parameters of biosorption of copper (II) and lead (II) ions onto pretreated Aspergillus niger. Biochem. Eng. J. 28, 187, 2006.

29. KUMAR R., BISHNOI N.R., GARIMA K., BISHNOI. Biosorption of chromium(VI) from aqueous solution and electroplating wastewater using fungal biomass, Chem. Eng. J. 135, 202, 2008

30. TUNALI S., AKAR T., OZCAN A.S., KIRAN I., OZCAN A. Equilibrium and kinetics of biosorption of lead (II) from aqueous solutions by Cephalosporium aphidicola, Sep. Purif. Technol. 47, 105, 2006.

31. AHLUWALIA, S.S., GOYAL, D. Microbial and plant derived biomass for removal of heavy metals from wastewater. Bioresour. Technol. 98, 2243, 2007.

32. PAHLAVANZADEH H., KESHTKAR A.R., SAFDARI J., ABADI Z. Biosorption of nickel(II) from aqueous solution by brown algae: equilibrium, dynamic and thermodynamic studies, J. Hazard. Mater. 175, 304, 2010.

33. SHENG P.X., TING Y.-P., CHEN J.P., HONG L. Sorption of lead, copper, cadmium, zinc, and nickel by marine algal biomass: characterization of biosorptive capacity and investigation of mechanisms. J. Colloid Interface Sci. 275, 131, 2004

34. LODEIRO P., CORDERO B., BARRIADA J.L., HERRERO R., DE VICENTE M.E.S. Biosorption of cadmium by biomass of brown marine macroalgae. Bioresour Technol. 96, 1796, 2005

35. CAZÓN J.P., BERNARDELLI C., VIERA M., DONATI E., GUIBAL E. Zinc and cadmium biosorption by untreated and calcium-treated Macrocystis pyrifera in a batch system. Bioresour. Technol. 116, 195, 2012. 
36. HAN X., WONG Y.S., TAM N.F.Y. Surface complexation mechanism and modeling in $\mathrm{Cr}$ (III) biosorption by a microalgal isolate, Chlorella miniata. J. Colloid. Interface. Sci. 303, 365, 2006.

37. FREITAS O.M.M., MARTINS R.J.E., DELERUE-MATOS C.M., BOAVENTURA R.A.R., Removal of Cd (II), Zn (II) and $\mathrm{Pb}$ (II) from aqueous solutions by brown marine macro algae: kinetic modelling, J. Hazard. Mater. 153, 493, 2008.

38. GUPTA V.K., RASTOGI A. Equilibrium and kinetic modelling of cadmium(II) biosorption by nonliving algal biomass Oedogonium sp. from aqueous phase. J. Hazard. Mater. 153, 759, 2008.

39. GUPTA V.K., SHRIVASTAVA A.K., JAIN N. Biosorption of chromium(VI) from aqueous solutions by green algae Spirogyra species. Wat. Res. 35, 4079, 2001.

40. GUPTA V.K., RASTOGI A. Biosorption of lead from aqueous solutions by green algae Spirogyra species: Kinetics and equilibrium studies. J. Hazard. Mater. 152, 407, 2008.

41. GUPTA V.K., RASTOGI A. Biosorption of hexavalent chromium by raw and acid-treated green alga Oedogonium hatei from aqueous solutions. J. Hazard. Mater. 163, 396, 2009.

42. GUPTA V.K., RASTOGI A., Nayak A. Biosorption of nickel onto treated alga (Oedogonium hatei): Application of isotherm and kinetic models. J. Colloid. Interface. Sci. 342, 533, 2010.

43. FAWZY M., NASR M., ADEL S., NAGY H., HELMI S. Environmental approach and artificial intelligence for $\mathrm{Ni}(\mathrm{II})$ and $\mathrm{Cd}(\mathrm{II})$ biosorption from aqueous solution using Typha domingensis biomass. Ecol. Eng. 95 , 743, 2016.

44. SRIVASTAVA S., AGRAWAL S.B., MONDAL M.K. Biosorption isotherms and kinetics on removal of $\mathrm{Cr}$ (VI) using native and chemically modified Lagerstroemia speciosa bark. Ecol. Eng. 85, 56, 2015.

45. YU H., PANG J., AI T., LIU L. Biosorption of $\mathrm{Cu}^{2+}, \mathrm{Co}^{2+}$ and $\mathrm{Ni}^{2+}$ from aqueous solution by modified corn silk: Equilibrium, kinetics, and thermodynamic studies. J. Taiwan Inst. Chem. Eng. 62, 21, 2016.

46. DISSANAYAKE D.M.R.E.A., WIJESINGHE W.M.K.E.H., IQBAL S.S., PRIYANTHA N., IQBAL M.C.M. Isotherm and kinetic study on $\mathrm{Ni}$ (II) and $\mathrm{Pb}$ (II) biosorption by the fern Asplenium nidus L. Ecol. Eng. 88, 237, 2016.

47. ZHOUA K., YANGA Z., LIUA Y., KONG X. Kinetics and equilibrium studies on biosorption of $\mathrm{Pb}$ (II) from aqueous solution by a novel biosorbent: Cyclosorus interruptus. J. Environ. Chem. Eng. 3, 2219, 2015.

48. TOUNSADI H., KHALIDI A., ABDENNOURI M., BARKA N. Biosorption potential of Diplotaxis harra and Glebionis coronaria L. biomasses for the removal of Cd(II) and $\mathrm{Co}(\mathrm{II})$ from aqueous solutions. J. Environ. Chem. Eng. 3, 822, 2015.

49. HU H., ZHANG J., LU K., TIAN Y. Characterization of Acidosasa edulis shoot shell and its biosorption of copper ions from aqueous solution. J. Environ. Chem. Eng. 3, 357, 2015.

50. VIJAYARAGHAVAN K., BALASUBRAMANIAN R. Is biosorption suitable for decontamination of metal-bearing wastewaters? A critical review on the state-of-the-art of biosorption processes and future directions. J. Environ. Manage. 160, 283, 2015.

51. SAG Y., YALCUK A., KUTSAL T. Use of a mathematical model for prediction of the performance of the simultaneous biosorption of $\mathrm{Cr}$ (VI) and $\mathrm{Fe}$ (III) on Rhizopus arrhizus in a semi-batch reactor. Hydrometallurgy. 59, 77, 2001.

52. FAGUNDES-KLEN M.R., FERRI P., MARTINS T.D., TAVARES C.R.G., SILVA E.A. Equilibrium study of the binary mixture of cadmium-zinc ions biosorption by the Sargassum filipendula species using adsorption isotherms models and neural network. Biochem. Eng. J. 34, 136, 2007.

53. VILAR V.J.P., LOUREIRO J.M., BOTELHO C.M.S., BOAVENTURA R.A.R. Continuous biosorption of $\mathrm{Pb} / \mathrm{Cu}$ and $\mathrm{Pb} / \mathrm{Cd}$ in fixed-bed column using algae Gelidium and granulated agar extraction algal waste. J.Hazard. Mater. 154, $1173,2008$.

54. MARTÍN-LARA M.A., BLÁZQUEZ G., CALERO M., ALMENDROS A.I., RONDA A. Binary biosorption of copper and lead onto pine cone shell in batch reactors and in fixed bed columns. Int. J. Miner. Process. 148, 72, 2016.

55. BAIG K.S., DOAN H.D., WU J. Multicomponent isotherms for biosorption of $\mathrm{Ni}^{2+}$ and $\mathrm{Zn}^{2+}$. Desalination. 249, 429, 2009.

56. LIU C-C., WANG M-K., CHIOU C-S., LI Y-S., YANG C-Y., LIN Y.A. Biosorption of chromium, copper and zinc by wine-processing waste sludge: Single and multi-component system study. J. Hazard. Mater. 171, 386, 2009.

57. SAG Y., AKCAEL B., KUTSAL T. Evalution, interpretation, and representation of three-metal biosorption equilibria using a fungal biosorbent, Process Biochem. 37, 35, 2001.

58. RODRIGUES M.S., FERREIRA L.S., DE CARVALHO J. C. M., LODI A., FINOCCHIO E., CONVERTI A. Metal biosorption onto dry biomass of Arthrospira (Spirulina) platensis and Chlorella vulgaris: Multi-metal systems. J. Hazard. Mater. 217-218, 246, 2012.

59. BAKATULA E.N., CUKROWSKA E.M., WEIERSBYE I.M., MIHALY-COZMUTA L., PETER A., TUTU H. Biosorption of trace elements from aqueous systems in gold mining sites by the filamentous green algae (Oedogonium sp.). J. Geochem. Explor. 144, 492, 2014.

60. TABARAKI R., NATEGHI A. Multimetal biosorption modeling of $\mathrm{Zn}^{2+}, \mathrm{Cu}^{2+}$ and $\mathrm{Ni}^{2+}$ by Sargassum ilicifolium. Ecol. Eng. 71, 197, 2014.

61. KLEINÜBING S.J., DA SILVA E.A., DA SILVA M.G.C., GUIBAL E. Equilibrium of $\mathrm{Cu}(\mathrm{II})$ and $\mathrm{Ni}(\mathrm{II})$ biosorption by marine alga Sargassum filipendula in a dynamic system: competitiveness and selectivity, Bioresour. Technol. 102, 4610, 2011.

62. MA X., CUI W., YANG L., YANG Y., CHEN H., WANG K. Efficient biosorption of lead(II) and cadmium(II) ions from aqueous solutions by functionalized cell with intracellular $\mathrm{CaCO}_{3}$ mineral scaffolds. Bioresour. Technol. 185, 70, 2015.

63. BAYO J. Kinetic studies for Cd(II) biosorption from treated urban effluents by native grapefruit biomass (Citrus paradisi L.): The competitive effect of $\mathrm{Pb}(\mathrm{II}), \mathrm{Cu}(\mathrm{II})$ and $\mathrm{Ni}(\mathrm{II})$. Chem. Eng. J. 191, 278, 2012.

64. REMENAROVA L., PIPISKA M., HORNIK M., ROZLOZNIK M., AUGUSTIN J., LESN J. Biosorption of cadmium andzinc by activated sludge from single and binary solutions: mechanism, equilibrium and experimental design study. J. Taiwan Inst. Chem. Eng. 43, 433, 2012.

65. RONDA A., MARTIN-LARA M.A., DIONISIO E., BLA'ZQUEZ G., CALERO M. Effect of lead in biosorption of copper by almond shell. J. Taiwan Inst. Chem. Eng. 44, 466, 2013.

66. HAJAHMADI Z., YOUNESI H., BAHRAMIFAR N., KHAKPOUR H., PIRZADEH K. Multicomponent isotherm for biosorption of $\mathrm{Zn}(\mathrm{II}), \mathrm{CO}(\mathrm{II})$ and $\mathrm{Cd}(\mathrm{II})$ from ternary mixture onto pretreated dried Aspergillus niger biomass. Water Resour. Ind. 11, 71, 2015.

67. KOOPAL L.K., VAN RIEMSDIJK W.H., DE WIT J.C.M., BENEDETTI M.F. Analytical isotherm equations for multicomponent adsorption to heterogeneous surfaces. J. Colloid. Interface. Sci. 166, 51, 1994. 
68. BABAK NOROOZI B., SORIAL G.A. Applicable models for multi-component adsorption of dyes: A review. J. Environ. Sci. 25 (3), 419, 2013.

69. WALTER J., WEBER J.R., MCGINLEY P.M., KATZ L.E. Sorption phenomena in subsurface systems: concepts, models and effects on contaminant fate and transport. Water Res. 25 (5), 499, 1991.
70. AL-ASHEH S., BANAT F., AL-OMARI R., DUVNJAK $Z$. Predictions of binary sorption isotherms for the sorption of heavy metals by pine bark using single isotherm data. Chemosphere. 41, 659, 2000. 
